\title{
Patriarchy and Women Abuse: Perspectives from Ancient Israel and Africa
}

\author{
SOLOMON OLUSOLA ADEMILUKA (UNISA)
}

\begin{abstract}
It is often claimed that women abuse inevitably emanates from patriarchy. Using ancient Israel and Africa as contexts, this article assesses the correlation between patriarchy and violence against women. The article suggests in these contexts, it is not all men are who are perpetrators of women abuse; rather, there is evidence of female perpetrators of sexual violence against men; and that in the ancient and modern societies, there is also homosexual violence. Rather than patriarchy, the major cause of women abuse is a personality disorder characterised, among other traits, by aggression against women, alcoholism and drug abuse - the latter two traits are often responsible for women abuse. Being accustomed to domestic violence from youth and low socio-economic status are also causes of women abuse.
\end{abstract}

Keywords: Ancient Israel; Africa; Patriarchy; Women abuse; Personality disorders

\section{A INTRODUCTION}

Women abuse is often blamed on patriarchy; in other words, maltreating women is claimed to be an inherent feature of every patriarchal culture. Using ancient Israel and Africa as contexts, this article assesses the correlation between patriarchy and violence against women. Thus, the article aims to find out the extent to which patriarchy is to blame for women abuse. To achieve this aim, I shall examine the concept of patriarchy as well as that of women abuse. I will also look at Israelite and African cultures as patriarchies, and examine the issue of violence against women in each of them. Finally, the article interrogates the correlation between patriarchy and the problem of women abuse.

\section{B THE CONCEPT OF PATRIARCHY}

The term 'patriarchy' originated from the Greek patriarkhēs, which literally means 'father of a race' or 'chief of a race.' Patriarchy therefore means 'the rule of the father.' ${ }^{1}$ Some authors trace patriarchy to the Latin words pater (father)

* Submitted: 02/04/2018; peer-reviewed: 18/07/2018; accepted: 24/07/2018. Solomon Olusula Ademiluka, "Patriarchy and Women Abuse: Perspectives from Ancient Israel and Africa," OTE 31 no. 2 (2018): 339-362. DOI: https://doi.org/10.17159/2312-3621/2018/v31n2a5.

"Patriarchy," London Feminist Network, online: https://tinyurl.com/y7yzrgzc. 
and $\operatorname{arch}$ (rule), in which case the term also means 'the rule of the father.' However, for Merriam Webster, the term 'patriarchy' is broader than this. She defines it as:

a social organization marked by the supremacy of the father in the clan or family, the legal dependence of wives and children, and the reckoning of descent and inheritance in the male line; broadly: control by men of a disproportionately large share of power. ${ }^{3}$

Thus, the author defines patriarchy in pragmatic terms; a definition that concurs with Igbelina-Igbokwe's view, namely that:

[Patriarchy] was originally used to describe the position of the father as a household head but it has progressively been used to refer to the systemic organization of male supremacy and female subordination ... Patriarchy is a system of social stratification and differentiation on the basis of sex which provides material advantages to males while simultaneously placing severe constraints on the roles and activities of females; with various taboos to ensure conformity with specified gender roles. ${ }^{4}$

In light of this definition, patriarchy is an organisational system in which males have dominance over females, and this domination is said to manifest "in the values, attitudes, customs, expectations, and institutions of the society, and maintained through the process of socialization."5 Describing the notion further along the view of domination over women, the London Feminist Network states that:

Patriarchy is the term used to describe the society in which we live today, characterised by current and historic unequal power relations between women and men whereby women are systematically disadvantaged and oppressed. It is particularly noticeable in women's under-representation in key state institutions, in decision-making positions and in employment and industry. Male violence against women is also a key feature of patriarchy. ${ }^{6}$

2 Christine Guarneri and Dudley L. Poston Jr., "Patriarchy," IESS online: https://tinyurl.com/y9djzlcf.

3 "Patriarchy," Merriam Webster Dictionary, https://tinyurl.com/y6wpaenl.

4 Nkiru Igbelina-Igbokwe, "Contextualizing Gender Based Violence within Patriarchy in Nigeria," PAVFJ 5/30 (2013): 630-32, Online: https://www.pambazuka. org/gender-minorities/contextualizing-gender-based-violence-within-patriarchynigeria.

5 Guarneri and Poston, "Patriarchy," http://www.encyclopedia.com/socialsciences/applied-and-social-sciences-magazines/patriarchy.

6 "What is Patriarchy?" London Feminist Network, https://tinyurl.com/y7yzrgzc. 
Thus, the London Feminist Network regards women abuse as an inherent part of patriarchy, a claim that anticipates my assessment of the correlation between the two issues.

Attempts have been made to trace the origin of patriarchy. Some find its origin in classical Greece sentiments among men and women, which limited women's values indoors and portrayed them as "morally, intellectually, and physically inferior to men." 7 Others find the emergence of patriarchy in a woman's biology which renders her more fit to perform roles such as "childrearing at home, rather than high-profile decision-making roles, such as leaders in battles." Scholars have also traced patriarchy to the second millennium B.C.E. in the context of "the rise of militarism, in the emerging archaic state system." "The victorious small group of male warriors asserted their dominance over those whom they conquered, usually including women and children, and consolidated their power through institutions that justified their superiority. Patriarchy developed from the view "that those outside the hegemonic male group were different from and inferior to the victorious males." 10

As noted earlier, some view women abuse as a key feature of patriarchy; and thus the need arises to examine the concept of women abuse, which is the focus of the next section.

\section{THE CONCEPT OF WOMEN ABUSE}

Women abuse or violence against women is better understood in the context of Intimate Partner Violence (IPV). As defined by the Centre for Disease Control and Prevention (CDC),

IPV encompasses acts of stalking, psychological aggression, physical violence or sexual violence-behaviors and tactics through which an intimate partner seeks to establish and maintain power over another. ${ }^{11}$

As further explained by the CDC, an intimate partner is a person with whom one has or had a close personal relationship that is characterised by

7 "Patriarchy," Wikipedia, https://tinyurl.com/y7yzrgzc.

8 "Patriarchy," Wikipedia, https://tinyurl.com/y7yzrgzc.

9 Vivian C. Fox, "Historical Perspectives on Violence against Women," JIWS 4/1 (2002): 15-34, online: http://vc.bridgew.edu/jiws/vol4/iss1/2/.

10 Fox, "Historical Perspectives," 15-34.

11 Cited in Kinsey Hasstedt and Andrea Rowan, "Understanding Intimate Partner Violence as a Sexual and Reproductive Health and Rights Issue in the United States," GPR 19 (2016): 37-45, online: https://tinyurl.com/ybup2fpn. 
emotional connectedness, regular contact, ongoing physical contact and/or sexual behavior, identity as a couple, familiarity and knowledge about each other's lives. ${ }^{12}$ partners." 13

Such a personal relationship could also exist "between gay and lesbian

Sexual violence is a very frequent form of IPV. The CDC defines it as:

an attempted or committed sexual act perpetrated against a person who has not freely given consent or is unable to refuse ... [which] includes rape, other forced or unwanted sexual contact. ${ }^{14}$

Sexual violence may occur in the form of:

completed or attempted, forced or alcohol/drug-facilitated unwanted vaginal, oral, or anal insertion ... [or] intentional touching of the victim or making the victim touch the perpetrator, either directly or through the clothing, on the genitalia, anus, groin, breast, inner thigh, or buttocks without the victim's consent...[It could be] unwanted exposure to sexual situations (e.g., pornography); verbal or behavioral sexual harassment; threats of sexual violence to accomplish some other end; and/or unwanted filming, taking or disseminating photographs of a sexual nature of another person. ${ }^{15}$

Apart from sexual violence, there are other forms of domestic violence, often collectively referred to as physical violence, and these are described in greater detail in the section on women abuse in Africa.

In summary, Intimate Partner Violence (IPV) refers to all acts that a person carries out to hurt another with whom he/she is/was in a relationship, such as between husband and wife or boyfriend and girlfriend. Women abuse therefore designates all such acts that men inflict upon women with whom they are or have been in some form of relationship, such as those carried out by husbands on their wives or boyfriends on their girlfriends. In a way, IPV is synonymous with women abuse in that, although there are women perpetrators of IPV, females are most often the victims. ${ }^{16}$ For example, while a rapist may be

12 “Intimate Partner Violence Prevention: Definitions, "Centers for Disease Control and Prevention, online: https://www.cdc.gov/violenceprevention/intimatepartnerviolence/definitions.html.

13 Richard J. Gelles, “Child Abuse," Microsoft Encarta 2009 [DVD] (Redmond, WA: Microsoft Corporation, 2008).

14 Cited by Hasstedt and Rowan, "Understanding Intimate Partner Violence," 37-45.

15 "Intimate Partner Violence Prevention: Definitions," Centers for Disease Control and Prevention, online: https://www.cdc.gov/violenceprevention/intimatepartner violence/definitions.html

16 Cheryl A. Kirk-Dugan, "Precious Memories: Rule of Law in Deuteronomy as Catalyst for Domestic Violence," in Exodus and Deuteronomy, ed. Athalya Brenner and Gale A. Yee (Minneapolis: Fortress, 2012), 259. 
a man or a woman, and rape can occur even in same-sex intercourse, "it is most often committed by a male against a female." 17

The prevalence of women abuse is attested all over the world. Folayan et al. affirm that worldwide women frequently "face tremendous sexual violence." 18 This fact is buttressed by a 2014 UNICEF report which confirms that "around 120 million girls worldwide ... have experienced forced intercourse or other forced sexual acts at some point in their lives." 19 According to Hasstedt and Rowan, large proportions of women in America have also experienced forms of IPV; "nearly half have experienced psychological aggression, approximately one in four have been subjected to severe physical violence, and nearly one in 10 have been raped." ${ }^{20}$ Kirk-Dugan similarly reports that,

According to the National Coalition against Domestic Violence Facts Sheet (Faith Trust Institute), about 1.3 million women are victims of physical assault by an intimate partner each year. Eighty-five percent of domestic abuse and violence are women, with women twenty to twenty-four years of age greatest risk for experiencing nonfatal, intimate partner violence. In domestic violence cases in the US, someone beats a woman every seven seconds; 30 percent of women in hospital emergency rooms seek treatment for domestic violence; 42 percent of female homicides are the results of domestic violence. ${ }^{21}$

\section{ANCIENT ISRAEL AS A PATRIARCHAL SOCIETY}

That ancient Israel was a patriarchal society is clearly depicted in the OT. As presented to us, "the Hebrew Bible is, in many respects, a man's book ... [I]t is a book that was primarily written by men, for men, and about men." 22 The main actors of that book are also predominantly male. In Ackerma's estimation, "over 90 percent of the 1400 or so individuals who are given names in the Hebrew Bible are men." 23 To illustrate the patriarchal nature of ancient Israel, I shall examine the status of women as reflected in the various portions of the OT in the following paragraphs.

17 "Rape," Encyclopadia Britannica Student and Home Edition (Chicago: Encyclopædia Britannica, 2011).

18 Morenike O. Folayan, Morolake Odetoyinbo, Abigael Harrison, and Brandon Brown, "Rape in Nigeria: A Silent Epidemic among Adolescents with Implications for HIV Infection," Global Health Action 7 (2014), DOI: https://doi.org/10.3402 lgha.v7.25583.

19 Morak Babajide-Alabi, “Let's Talk about Rape," Vanguard 17 September 2017, https://tinyurl.com/ybdrwopv.

20 Hasstedt and Rowan, "Understanding Intimate Partner Violence," 37-45.

21 Kirk-Dugan, "Precious Memories," 262.

22 Susan Ackerman, "Women in Ancient Israel and the Hebrew Bible,"ORER (April 2016), 32 pages, DOI: https://doi.org/10.1093/acrefore/9780199340378.013.45.

23 Ackerman, "Women in Ancient Israel," 2. 
In the Jahwistic creation account (Gen 2:4b-25), Adam is not only created before Eve, but the woman is formed from his rib so that "in a sense, he may be considered her parent ... As such, Adam is clearly in the dominant position."24 Furthermore, Yahweh gives Adam the authority to name all that he, Yahweh, has created, including the woman (Gen 2:7). The naming of Eve by Adam probably indicates that the man has authority over the woman, because "in ancient times, one was believed to have authority over a person or thing by naming it." ${ }^{25}$ This fact seems to be supported in Gen 3:16 where Adam's role is to "rule over" Eve (KJV, NIV, RSV). Fox observes that the "rib version" of the creation narrative, as against the Priestly account (Gen 1:1-2:4a), "has predominated for thousands of years, reinforcing the subordinate position of women." 26

In Israelite laws, "a woman was the property of her father or her husband." 27 For example, in the Ten Commandments "the wife is clearly regarded as equivalent to a piece of property," 28 as she is listed along with her husband's other belongings (Exod 20:17). Hence, Collins (in Ademiluka) rightly affirms that "Women were regarded as an inferior species to be owned like cattle ..."29 In Exod 22:16-17, it is stated that if a man violates a virgin, it is "viewed as a property offense against the woman's father." 30 If her father refuses marrying her daughter off to the violator, the latter must pay money to him "to compensate the girl's father appropriately for the reduced price she would fetch, given the loss of her virginity." 31 This law is similar to that of Deut 22:13-21. If, upon marrying a woman, the husband accuses his wife of not being a virgin, and "the charges are false, the husband owes his wife's father a payoff and has to stay in the marriage." 32 Thus, "in biblical times, acts of sexual assault and abuse against women were of concern to the degree that they violated male property rights." 33 Jacobs finds the patriarchal motive of the provisions of these laws in

24 Guarneri and Poston, "Patriarchy," http://www.encyclopedia.com/socialsciences/applied-and-social-sciences-magazines/patriarchy.

25 B. A. Robinson, "Passages in the Hebrew Scriptures (Old Testament) that Treat Women as Inferior to Men," Religious Tolerance, https://tinyurl.com/b7dv9.

26 Fox, "Historical Perspectives," 15-34.

27 Kirk-Dugan, "Precious Memories," 260.

28 Robinson, "Passages in the Hebrew Scriptures," https://tinyurl.com/b7dv9.

29 Shiella Collins, "Towards a Feminist Theology," ChrCent 89 (1972): 792-804, cited in S. Olusola Ademiluka, "1 Corinthians 14:33b-36 in Light of Women and Church Leadership in Nigeria," VetE 38/1 (2017); article \#1672; DOI: https://doi.org/ 10.4102/ve.v38i1.1672

30 Robinson, "Passages in the Hebrew Scriptures, "https://tinyurl.com/b7dv9.

31 Sandra Jacobs, "Terms of Endearment? The Desirable Female Captive and her Illicit Acquisition," in Exodus and Deuteronomy, ed. Athalya Brenner and Gale A. Yee (Minneapolis: Fortress, 2012), 247.

32 Kirk-Dugan, "Precious Memories," 273.

33 Naomi Graetz, "Domestic Violence in Jewish Law," My Jewish Learning, https://tinyurl.com/ycw9bnue. 
the fact they do not indicate any concern for the physical or emotional injury of the victim.... [R]ather they stipulate the terms under which a man may commit rape, provided he pays reparation to the offended male party. ${ }^{34}$

Israelite laws of inheritance similarly reveal the patriarchal nature of that society. In Num 27:8-11, it is stated that if a man dies, his son inherits the estate; his daughter inherits only if there is no son. If there are no children, the consideration is for male relatives, not the females. ${ }^{35}$ Patriarchy is reflected also in a marriage relationship in which the husband is called " $b a$ ' $a l$ which implies both ownership and lordship" (Exod 21:28). ${ }^{36}$ That is why "if a wife is physically harmed by someone, compensation is paid to her husband" (21:22). ${ }^{37}$ In Deut 22, it is stated that the husband/father, as head of the household, has "extensive power, given the power of the state and local council... [The husband] controls terms of marriage, his wife's sexuality and familial economic matters." 38 In Deuteronomy, it is also noted that only the husband has the right to initiate divorce $(24: 1)$.

Sources outside the OT also testify that the Jewish society from the postexilic period onwards was no less patriarchal. For example, in synagogue worship, the part of women "was strictly receptive," 39 and they were not allowed the oral reading of the law. In fact, the rabbis held the ideology that "[i]t is better that the words of the law should be burned ... than they should be given to women." 40 This point concurs with in Baumert's (in Ademiluka) view that:

in Judaism there were firmly established customs to the effect that women by themselves could not conduct an official worship service, but could only come together for prayer ... [whereas] a service in the synagogue required the presence of at least ten men. ${ }^{41}$

Discrimination against women was not limited to religious matters. Women "were not allowed to testify in court trials....[nor] go out in public, or talk to strangers." 42

From the discussion above, it is no surprise that many are of the view that ancient Israelite patriarchy inevitably engendered women abuse. For example,

\footnotetext{
34 Jacobs, "Terms of Endearment," 241.

35 Robinson, "Passages in the Hebrew Scriptures," https://tinyurl.com/b7dv9.

36 Robinson, "Passages in the Hebrew Scriptures," https://tinyurl.com/b7dv9.

37 Graetz, "Domestic Violence," https://tinyurl.com/ycw9bnue.

38 Kirk-Dugan, "Precious Memories," 274.

39 Ademiluka, "1 Corinthians 14:33b-36," 2.

40 In Ademiluka, "1 Corinthians 14:33b-36," 2.

41 Norbert, S. J. Baumert, Woman and Man in Paul: Overcoming a Misunderstanding, trans. Patrick Madigan, S. J., and Linda M. Maloney (Collegeville, Minnesota: Michael Glazier, 1996), cited in Ademiluka, "1 Corinthians 14:33b-36," 3.

42 Robinson, "Passages in the Hebrew Scriptures," https://tinyurl.com/b7dv9.
} 
Kirk-Dugan opines that the socio-cultural context that produced Israelite "laws expresses a reality where the construction of male identity and subjectivity inevitably seemed to rely on violence against women." ${ }^{43}$ Later on in this article I shall assess the correlation between patriarchy and women abuse, but before this, I will examine the prevalence of women abuse in ancient Israel as reflected in the OT.

\section{E WOMEN ABUSE IN ANCIENT ISRAEL}

Greatz affirms that "there is much data demonstrating that domestic abuse is a significant $\ldots$ behavior in Jewish communities in Israel and the Diaspora." ${ }^{44}$ Unfortunately, the material available on this subject in the OT relates only to sexual abuse. Graybill states that ancient Israel had a "rape culture ... [as] many of the features that contemporary commentators identify as central to rape culture appear in the Hebrew Bible." ${ }^{45}$ I will now examine a number of texts in which women are sexually abused. I begin with the narrative of the Levite and his concubine in Judg 19, because many consider it to be the most heinous acts of sexual abuse in the OT.

According to Graybill,

The most notorious rape narrative in the Hebrew Bible is the story of the Levite's concubine in Judges 19. A Levite and his concubine are traveling through the land of Benjamin and must spend the night in Gibeah. A man gives them shelter for the night, but the men of the city surround the house and demand the opportunity to rape the Levite ... [T] he host offers instead the concubine and his own virgin daughter; the men refuse, but the Levite pushes out his concubine. She is raped all night and [her dead body] discovered in the morning. ${ }^{46}$

This story is similar to the one in Gen 19:8-11 where Lot offers his two daughters to certain men of Sodom who desire to rape his male guests. It is important to note that in these texts, like the daughter of Jephthah narrative (Judg 11:29-40), the women are not named. ${ }^{47}$ However, it is more important for the present study that in both texts alternate targets are provided for the rapists, which points "to the larger economy of sexual violence" and the representation of "women as interchangeable sexual commodities." 48 Furthermore, the

43 Kirk-Dugan, "Precious Memories," 278.

44 Graetz, "Domestic Violence," https://tinyurl.com/ycw9bnue.

45 Rhiannon Graybill, "Teaching about Sexual Violence in the Hebrew Bible," Oxford Biblical Studies Online, https://tinyurl.com/yd9s887q.

46 Graybill, "Teaching," https://tinyurl.com/yd9s887q.

47 Cf. Juliana L. Claassens, "Female Resistance in Spite of Injustice: Human Dignity and the Daughter of Jephthah," OTE 26/3 (2013): 607-22.

48 Graybill, “Teaching," https://tinyurl.com/yd9s887q. 
intertextual connections between Gen 19 and Judg 19 indicate that rape culture "is pervasive across biblical texts, times, and authors." 49

In anticipation of the discussion on the correlation between patriarchy and women abuse, it is also important to note that the two narratives point to the possibility of males being victims of sexual violence in the ancient Israelite society. In Gen 19, the Sodomites demanded that Lot bring out his male visitors so "that we may know them" (v.5), just as the men of Gibeah told the Levite's host to bring him out because they wanted to "know him" (Judg 19:22). The Hebrew verb used in both texts is ידע (to know), which is used to express "a multitude of shades of knowledge gained by the senses." 50 One of them is carnal knowledge, that is, "sexual intercourse on the part of both men and women [as] in the well-known euphemism "Adam knew Eve his wife," 51 the euphemism which is commonplace in the HB (cf. Gen 4:1; Gen 19:8; Num 31:17, 35; Judg $11: 39 ; 21: 11 ; 1 \mathrm{Kgs} 1: 4 ; 1$ Sam 1:19). Coffman affirms that the verb as used in both texts "is a euphemism for homosexual intercourse" 52 while Schultz opines that the scene in Gen 19 portrays gang rape and homosexuality. ${ }^{53}$ That homosexual rape is intended in Judg 19 is confirmed in v. 25 where ידע is used for raping the Levite's concubine. The suggestion that men were most likely raped in ancient Israel is equally buttressed in Gen 19:32-38 where "Lot himself is raped by his daughters, who believe there is no other man left alive to father children." ${ }^{54}$ Some interpreters similarly interpret a homosexual rape meaning in Gen 9:22-25 where Noah is drunk and asleep, and his son, Ham, sees his nakedness and tells his (Ham's) brothers. ${ }^{55}$

In Gen 34 Dinah, the only daughter of Jacob, goes out to visit the women in the neighbourhood (34:1) and then Shechem rapes her. After the assault, Shechem desires to marry Dinah. His men fall for Dinah's brothers' deception that she will be given to him on the condition that Shechem's men are circumcised. The latter agree to this but, while Shechem's men are still recuperating, Dinah's brothers kill them. Various interpretations have been offered for Dinah's experience. Some see it as consensual premarital sex, in

49 Graybill, “Teaching," https://tinyurl.com/yd9s887q.

50 Paul R. Gilchrist, "ידע,", in TWOT 2:360.

51 Gilchrist, TWOT 2:360.

52 James B. Coffman, "Commentary on Judges 19:4," Coffman Commentaries on the Old and New Testament (Abilene, TX: Abilene Christian University Press, 1983-1999), online: https://www.studylight.org/commentaries/bcc/judges-19.html.

53 John Schultz, "Genesis 19 - Commentary," https://tinyurl.com/ycopw77o.

54 Graybill, "Teaching," https://tinyurl.com/yd9s887q. However, the author notes that some have suggested that it was Lot who raped his daughters but the text in its present form "reflects either bad conscience or an intentional cover-up."

55 However, this interpretation seems unlikely, and has been accordingly dismissed by many. See, e.g., Gordon J. Wenham, "Genesis," in New Bible Commentary, ed. Donald A. Carson, et al. (Nottingham: IVP, 1994), 56. 
which case her experience is "a doomed love story," 56 but Klopper regards Dinah's encounter with Shechem as "a classic case of acquaintance, or date rape." 57 Graybill observes that the Dinah narrative depicts several "issues surrounding rape, female sexuality, and the status of women in the biblical text." One of them is that the girl's sexuality is presented as "something to be negotiated and exchanged among men." 58 Similar to "the sexual use of women captured in warfare" (Deut 21:10-14), ${ }^{59}$ Dinah's case may be understood in the context of "female sexuality as an extension of masculine economies of power and control in the Hebrew Bible." 60

The culture of women's sexuality that is regarded as a means of "establishing power relations between men" 61 is equally reflected in the Tamar narrative (2 Sam 13) where Absalom seeks to defend his sister. However, this is probably expressed most clearly in 2 Sam 16:21-22 where the same Absalom, heeding Ahithophel's advice, demonstrated "his assumption of royal power and prerogative by intercourse with his father's concubines." 62 In the course of Absalom's rebellion against David, the latter had fled Jerusalem leaving, "ten of his concubines to keep his palace." ${ }^{63}$ It should be pointed out that the violation of his father's concubines was part of the power struggle between Absalom and David, as in the ancient world "taking of the wives of the predecessor was a part of the succession." 64

The rape culture in ancient Israel is also observable in "larger conditions of culture." ${ }^{65}$ For example, the use of slave women such as Hagar, Zilpah, and Bilhah in Gen as surrogates for their barren mistresses can be seen as "sexual exploitation of slaves." 66 Some interpreters of the David and Bathsheba narrative regard Bathsheba's "action of bathing on the roof as an invitation to sexual activity [which] ... evokes the common rape culture narrative of 'asking for it. " ${ }^{67}$ However, this is another story that raises the issue of masculine power and

56 Graybill, “Teaching,” https://tinyurl.com/yd9s887q.

57 Frances Klopper, "Rape and the Case of Dinah: Ethical Responsibilities for Reading Genesis 34," OTE 23/3 (2010): 658.

58 Graybill, “Teaching," https://tinyurl.com/yd9s887q.

59 Graybill, “Teaching," https://tinyurl.com/yd9s887q.

60 Graybill, "Teaching," https://tinyurl.com/yd9s887q.

61 Graybill, "Teaching," https://tinyurl.com/yd9s887q.

62 Leonard H. Brockington, "I and II Samuel," in Peake's Commentary on the Bible, ed. Matthew M. Black and Harold H. Rowley (Wokingham: Van Nostrand Reinhold, 1982), 335.

63 Charles W. Smith, "Commentary on 2 Samuel 16:4,"Chuck Smith Bible Commentary (2014), https://tinyurl.com/y9ctcja8.

64 Smith, “2 Samuel 16:4,” https://tinyurl.com/y9ctcja8.

65 Graybill, “Teaching," https://tinyurl.com/yd9s887q.

66 Graybill, "Teaching," https://tinyurl.com/yd9s887q.

67 Graybill, "Teaching," https://tinyurl.com/yd9s887q. 
control in the sense that Bathsheba was not in position to reject "the king's sexual propositions." 68

\section{F AFRICAN CULTURE AS A PATRIARCHY}

Similar to ancient Israel, patriarchy is very much a part of African life, and is deeply entrenched in the "norms, values and customs" ${ }^{\text {" }}$ of this continent. In subSaharan Africa, as was the case in ancient Israel, the male is lord over the female; "it is the males' will and cultural norms which dominate and legislate." ${ }^{70}$ Men are born already elevated in the societal hierarchy, and men and male children are valued above women and female children. ${ }^{71}$

This domination over women is reflected right from the process of contracting a marriage during which a man pays a bride price for his wife, which makes her the property of her husband. The idea that the husband owns his wife is symbolised in various ways. For example, in most parts of Nigeria, "the act of payment of bride price ... is perceived as an outright act of transfer of woman's rights in source family to spouse's family." 72 Also, in most places in Africa after the wedding, the woman is compelled by tradition to bear her husband's name as surname, dropping her father's name. ${ }^{73}$

In Africa, therefore, "the sexuality of married women is perceived to be in the domain of the control of their husbands." ${ }^{" 74}$ For example, in Botswana even a single-parent woman does not have the right to consort with any man other than the one for whom she bears children; in other words, tradition does not allow a woman to keep two men at a time. A man is free to have a second wife or a concubine if he so wishes "whilst the woman, a concubine or second wife should always be faithful to one man." ${ }^{\text {" }} 5$ Discrimination against women is also seen in the traditional injunction on young women to abstain from sexual intercourse before marriage, whereas there is no such restriction on young men, or on older

68 Graybill, “Teaching," https://tinyurl.com/yd9s887q.

69 Godess Bvukutwa, "Gender Equality is not a Western Notion," Imagining Equality, https://tinyurl.com/y8vy6frb.

70 Lere Adeyemi, "The Yoruba Cultural Values and the Ideology of Feminism," in Multi-disciplinary Perspectives in Nigerian Studies, ed. Rotimi Ajayi, Olu Alana, and Yemi Akinwumi (Ilorin: Nathdex, 1998), 49.

71 Bvukutwa, "Gender Equality," https://tinyurl.com/y8vy6frb.

72 Igbelina-Igbokwe, "Contextualizing," 630-32.

73 Adeyemi, "Yoruba Cultural Values," 52.

74 J. Madipoane Masenya, "Drippling Nails, Desire and Polygynous Partnerships: Navigating Women's Stories in Gen 29-30 through African Love Song(s)," ThViat 36/1 (2012): 128.

75 Obed N. Kealotswe, "Biblical and African Forms of Marriage and Old Testament Prophecy: An Interpretation of Isaiah 4:1 in the Era of HIV/AIDS by an African Independent Church Leader in Botswana," ThViat33/3 (2009):302. 
men from marrying younger girls. ${ }^{76}$ It is true that the enforcement of abstinence from sex before marriage reflects the African value of virginity, but:

it becomes discriminatory when the expectation and responsibility of chastity becomes the burden of women/daughters while rascality and high risk sexual behavior is tolerated and encouraged for men and boys by the society. ${ }^{77}$

At the household level, patriarchy is also reflected in gender role differentiation. Apart from the natural role of childbearing, in the traditional African society, women played roles predominantly prescribed by men, usually domestic roles. The prevailing practice was polygyny, with each wife being accorded rights as determined by the husband who was the lord of the house. The wives required the husband's permission on practically every issue, movement, interaction as well as procreation. In the polygynous setting, each wife had the additional and endless duty of seeking the husband's favour, sometimes by fighting with the other wives. ${ }^{78}$ It is important to note that these practices still persist in many parts of Africa, especially in rural areas. Another sphere where women suffer discrimination at the family level is that of inheritance. In Africa, as in ancient Israel, the right of inheritance excludes women. Among the Igbo of south-eastern Nigeria, for instance:

if a husband dies intestate, the woman usually receives nothing ...

[And] since property can only pass between the same sexes, women are [also] not expected to inherit from their fathers. ${ }^{79}$

Discrimination against girl children is a crucial aspect of African patriarchy. In many parts of sub-Saharan Africa, a male child is often preferred to a female, the major reason being that girls are "perceived as expendable commodities who will eventually be married out to other families to procreate and ensure the survival of the spouses' linage by bearing sons." 80 Oftentimes, in the bid to have male children, many men would take a second wife if the first one is unable to bear male children. Hence, a concomitant effect of this preference on womanhood is that "a woman with no sons is plagued with social insecurity as she lives in constant fear of losing her marriage and her homestead to another woman." ${ }^{81}$ Not attaching much value to a girl child may be one of the

76 Masenya, "Drippling Nails," 128.

77 Igbelina-Igbokwe, "Contextualizing," 630-32.

78 Oyeronke Olajubu, "Culture as an Empowering Tool in Africa: A Feminist Perspective," in Multi-Disciplinary Perspectives in Nigerian Studies, ed. Rotimi Ajayi, Olu Alana, and Yemi Akinwumi (Ilorin: Nathdex, 1998), 61; cf. Adeyemi, "Yoruba Cultural Values,"52.

79 Igbelina-Igbokwe, "Contextualizing," 630-32.

80 Igbelina-Igbokwe, "Contextualizing," 630-32; cf. Bvukutwa, "Gender Equality," https://tinyurl.com/y8vy6frb.

81 Igbelina-Igbokwe, "Contextualizing," 630-32. 
reasons why some parents force young girls into early marriage. For example, there is the practice of ukuthwala in South Africa, especially "in rural Eastern Cape and KwaZulu-Natal... where girls, sometimes as young as 9 years old ... are forced into marriage." $" 82$

At the public level, the status of the African woman is not any higher. In traditional community governance, women play an insignificant role. In most parts of Nigeria, for example, they "have no say in the settling of disputes, making of laws governing the conduct of the society or the distribution and maintenance of land." ${ }^{83}$ Writing on South Africa, Mkhize opines that the gender gap between men and women "continues to persist in economic, social and political spheres." ${ }^{84}$ This gap was widened in most African countries that have been colonised by the western world. According to Igbelina-Igbokwe,

Colonization deepened the gender chasm through entrenching and reinforcing discriminatory gender division of roles for women and men which encouraged the supremacy and importance of men's over women's roles. The economic systems introduced by colonialism denied women the use of public space and confined them to the domestic sphere. The implication was the further invisibilization of women and the negation of their economic, political and social roles. ${ }^{85}$

Scholars have called attention to the roles played by women who themselves help to sustain patriarchy in Africa. Igbelina-Igbokwe affirms that,

[patriarchal system] is successfully perpetuated through cultural and religious socialization to the degree that most girls and adolescent women ... grow into adult women believing that these occurrences are natural and divinely ordered. ${ }^{86}$

Hence, most often adult women resist change; for them, any call for gender equity is "an aberrance to cultural dictates of appropriateness of behavior for women and men." 87 As Mkhize puts it, "Patriarchy remains deeply entrenched within the fabric of our society to such an extent that most women consider it to be a normal way of life." ${ }^{88}$ Similarly, Bvukutwa states that

82 Kholofelo Mokgata, "African Culture should Adopt Feminism: A Look at how Patriarchy has Tarnished African Culture," Unlabelled, https://tinyurl.com/ya5o5fog.

83 Olajubu, "Culture," 61.

84 Zweli Mkhize, "Patriarchy: A Catalyst for Gender Violence and Discrimination," Daily Maverick 18 September 2017, https://tinyurl.com/yc2srjya.

85 Igbelina-Igbokwe, "Contextualizing," 630-32.

86 Igbelina-Igbokwe, "Contextualizing," 630-32.

87 Igbelina-Igbokwe, "Contextualizing," 630-32.

88 Mkhize, "Patriarchy," https://tinyurl.com/yc2srjya. 
patriarchy has been so entrenched in Africa because it is "using women as its guardian." 89

\section{G WOMEN ABUSE IN AFRICA}

The explanation of African patriarchy above reveals that in Africa "societal expectation of subservience of the female is a commonly accepted phenomenon." ${ }^{90}$ Hence, many cannot "separate African culture from systems that oppress the freedoms of African women." 91 In other words, many would see a direct link between patriarchy and women abuse in Africa, as was the case in ancient Israel. The correlation between patriarchy and women abuse is the subject of the last section of this article; in the present section I first examine women abuse in Africa.

Unlike in ancient Israel where evidence of women abuse is described only in terms of sexual violence, in Africa there is evidence of other forms of violence against women. In 2008, the UN deemed the DR Congo the most sexually violent country in the world; whereas "a 2009 study ... showed that more than a quarter of South African men said they had committed rape."92 In Nigeria, some "reports have shown that 4-6\% of all adolescent girls in southwestern Nigeria experience rape." 93 In Africa, there is no age limit to rape; "children, babies, adolescents, matured adults, mothers, grandmothers ... are being raped."94 There are several dimensions to rape, including gang raping and raping under duress, sometimes at gunpoint. There is also the spiritual dimension as some people, including 'men of God' use charms to seduce girls "with the intention of getting rich." "Some 'prophets' do 'spiritual cleansing' or 'deliverance' for women by means of sexual intercourse, while some men rape young girls because they believe "having sexual intercourse with underage children could cure them of the dreaded HIV/AIDS disease." 96 Some rapists also take advantage of disabled women and violate them. Baffour reports that "rapists were taking undue advantage of deaf girls to commit their heinous crime ..."97 The concept of 'sugar daddies' is also well-known in Africa. These are elderly men who "take advantage of girls' lack of economic resources by promising to help with their

89 Bvukutwa, "Gender Equality,” https://tinyurl.com/y8vy6frb.

90 Igbelina-Igbokwe, "Contextualizing," 630-32.

91 Mokgata, “African Culture,"https://tinyurl.com/ya5o5fog.

92 "Rape," Encyclopadia Britannica.

93 Folayan, et al., "Rape in Nigeria," DOI: https://doi.org/10.3402/gha.v7.25583.

94 Katherine Baffour, "Rape in Nigeria: Sexual Predators on the Prowl," NAIJ.com, https://tinyurl.com/y74ae27n.

95 Baffour, "Rape in Nigeria," https://tinyurl.com/y74ae27n.

96 Baffour, "Rape in Nigeria," https://tinyurl.com/y74ae27n.

97 Baffour, "Rape in Nigeria," https://tinyurl.com/y74ae27n. 
expenses in exchange for sex." 98 This practice is rampant in Kenya, Uganda, Tanzania, among other countries. ${ }^{99}$

There are other forms of domestic violence in which women are most often at the receiving end. In the enumeration of Antai, in Nigeria, for example, acts of physical violence against women other than the sexual include:

i) pushing, shaking or throwing something at her; ii) slapping her or twisting her arm; iii) punching or hitting her with something harmful; $i v$ ) kicking or dragging her; v) strangling or burning her; vi) threatening her with a weapon (e.g., gun or knife); and vii) attacking her with a weapon. ${ }^{100}$

Igbelina-Igbokwe includes other acts such as:

wife battery... acid bath, harmful traditional practices (e.g., female genital mutilation), widowhood rites/disinheritance, deprivation of material and economic resources [and] ... restriction of mobility... ${ }^{101}$

Delano affirms that these forms of abuse are widespread across subSaharan Africa. According to the author:

Surveys conducted in sub-Saharan Africa reveal that 46 percent of Ugandan women, 60 percent of Tanzanian women, 42 percent of Kenyan women, and 40 percent of Zambian women report regular physical abuse. In a Nigerian survey, 81 percent of married women report being verbally or physically abused by their husbands. Fortysix percent report being abused in the presence of their children. ${ }^{102}$

Wife beating seems to be the most prevalent of physical violence towards women, perhaps because in many places corporal punishment for wives "is widely sanctioned as a form of discipline." 103 Hence, when men beat their wives they "believe they are instilling discipline in them ... [as women] are regarded as children who can be prone to indiscipline if not 'disciplined."' 104

98 Lola Delano, "Sexual Abuse and Violence in Sub-Saharan Africa," Advocates for Youth, https://tinyurl.com/q5her32.

99 Delano, "Sexual Abuse," https://tinyurl.com/q5her32.

100 Diddy Antai, "Controlling Behavior, Power Relations within Intimate Relationships and Intimate Partner Physical and Sexual Violence against Women in Nigeria," BMCPH 11 (2011), 11 pages, doi: 10.1186/1471-2458-11-511, 3.

101 Igbelina-Igbokwe, "Contextualizing," 630-32.

102 Delano, “Sexual Abuse,” https://tinyurl.com/q5her32.

103 Aihie N. Ose, "Prevalence of Domestic Violence in Nigeria: Implications for Counseling," EJC2/1 (2009), 8 pages, doi: 10.4314/ejc.v2i1.52648, 3.

104 Josephine Agbonkhese and Chris Onuoha, "Does Nigerian Culture Permit Domestic Violence?" Vanguard 24 August 2017, https://tinyurl.com/ybyukpcw. 
Unfortunately, in some places (e.g., Nigeria ${ }^{105}$ ), the women themselves "believe that physical abuse is most times justified," 106 thus buttressing the fact that women are sometimes guardians of patriarchy.

\section{H IS PATRIARCHY THE CAUSE OF WOMEN ABUSE?}

In view of the fact that "subordination ... and oppression of women"107 are witnessed in patriarchal cultures, many believe that women abuse is inherent in patriarchy. It is claimed that violence against women inevitably occurs in traditional milieus that "put women beneath men in status and personhood." ${ }^{108}$ In the words of Becker:

the oppression of women is certainly an important part of patriarchy . [A] social system that is male-identified, male-controlled, malecentered will inevitably value masculinity and masculine traits over femininity and feminine traits. ${ }^{109}$

It is apparent that in traditions such as those of ancient Israel and Africa as discussed above seem to sanction violence against women. Typically, there are those who view women as the property of their husbands or fathers. ${ }^{110}$ In the course of this study, for example, I pointed out that in Israelite laws, a woman was owned by her father or husband. These laws would most likely encourage violence against women, since all that a perpetrator needed to do was to pay compensation to a victim's father. Also, as noted, the treatment of women as one's personal property seems to be reflected in the narrative of the Levite and his concubine in Judg 19. The Levite owned his woman and could treat her as he wished, including using her as an exchangeable sexual commodity. Similar African customs are likely to induce women abuse. Igbelina-Igbokwe ${ }^{111}$ observes a correlation between patriarchy and women abuse in the advice that some women give to their daughters when giving them out in marriage. In some areas in Nigeria, for instance, during the traditional wedding, most parents encourage their daughters to remain in their marriages, irrespective of the circumstances they face in their matrimonial homes. This type of advice, coupled

105 Leah Okenwa,Stephen Lawoko, and Bjarne Jansson, "Factors Associated with Disclosure of Intimate Partner Violence among Women in Lagos, Nigeria," JIVR 1/1(2009): 37-47; doi: 10.5249/jivr.v1i1.15.

106 Monica Agene, "The Reality of Domestic Violence in Nigeria," Women for Women International, https://tinyurl.com/yc4g5gfv.

107 Mary Becker, "Patriarchy and Inequality: Towards a Substantive Feminism," UCLF 1/3 (1999): 21-88, article \#3,online: https://chicagounbound.uchicago.edu /uclf/vol1999/iss1/3/, 24.

108 Samantha Gluck, "Causes of Domestic Violence, Domestic Abuse," Healthy Place, https://tinyurl.com/yagkd4fl.

109 Becker, "Patriarchy," 24.

110 Kirk-Dugan, "Precious Memories," 258

111 Igbelina-Igbokwe, "Contextualizing,"630-32. 
with the custom of the bride price (which gives the husband the impression that he has paid off his father-in-law), may not inspire men to put up with inadequacies on the part of their wives.

The above arguments thus prove that patriarchy can engender women abuse. However, there are counter-arguments that suggest that there are personal factors, rather than patriarchy, underlying women abuse. In the first place, as mentioned earlier, my study of the Levite and his concubine narrative in Judg 19 and that of Lot and his divine visitors in Gen 19 reflects the fact that, sometimes, men were targets of sexual abuse. In fact, the narrative of the rape of Lot by his daughters (Gen 19:32ff) indicates the presence of women rapists in ancient Israel. Also, as mentioned earlier, in the modern world, there is evidence of women perpetrators of violence against men. Kirk-Dugan further affirms this when she notes that, "While most perpetrators of domestic and sexual violence are men, we recognize there are times when women engage in these acts." 112 This point is buttressed by the Department of Justice of the United States which records that,

men were victims in about 150000 incidents of intimate violence in 1996. The department's data indicate that women are about six times as likely as men to experience victimization by an intimate partner. However, in a privately funded survey conducted in 1993, American men and women reported experiencing similar rates of intimate violence. ${ }^{113}$

In a study conducted in South Africa by Kalichman et al., it was found that "over $40 \%$ of women and $16 \%$ of men had been sexually assaulted." 114

From the above, it is clear that at times women as well as men are victims of gender violence, and that women can also be perpetrators of gender violence against men. It should also be noted that not all men in the two contexts examined, or in any given patriarchy for that matter, indulge in violence against women. To this end, some believe that it is wrong to blame domestic violence on any factors, patriarchy inclusive; for them, it "is a matter of choice for perpetrators." "115 However, I, we believe that there are factors that cause men to abuse women, but that patriarchy is not the actual cause. I acknowledge that a patriarchal culture may induce violence against women, but "violent behavior

112 Kirk-Dugan, "Precious Memories," 259.

113 Gelles, "Domestic Violence."

114 Seth C. Kalichman, Leickness C. Simbayi, Michelle Kaufman, Demetria Cain, Chauncey Cherry, Sean Jooste, "Gender Attitudes, Sexual Violence, and HIV/AIDS Risks among Men and Women in Cape Town, South Africa," JSR 42/4 (2005): 299305, DOI: https://doi.org/10.1080/00224490509552285, 299.

115 "Causes of Domestic Abuse," Living without Abuse, https://tinyurl.com/y9r8all3. 
often is caused by an interaction of situational and individual factors." 116 Hence, in the rest of this section, I shall consider some of these individual factors.

One major individual factor that would explain why, in a given patriarchy, some men perpetrate women abuse, especially sexual violence, while others do not is personality disorder. Also known as character disorder:

Personality disorder is a mental disorder that is marked by deeply ingrained and lasting patterns of inflexible, maladaptive, or antisocial behaviour. A personality disorder is an accentuation of one or more personality traits to the point that the trait significantly impairs an individual's social or occupational functioning. Personality disorders are not, strictly speaking, illnesses, since they need not involve the disruption of emotional, intellectual, or perceptual functioning. ${ }^{117}$

One type of personality disorder is:

the antisocial, sociopathic, or psychopathic personality disorder ... [which] is chiefly characterized by a personal history of chronic and continuous antisocial behaviour in which the rights of others are violated. ${ }^{118}$

Most of the criminals in society display characteristics of this disorder, the symptoms of which may "include sexual promiscuity or sexual aggression and drug addiction or alcoholism." "119 The idea that rapists have an antisocial disorder is buttressed by Newman who notes that, "For a man to commit sexual assault, he must be a relatively ... antisocial person - enough that he isn't too constrained by empathy for his victims." 120 This fact is confirmed by a study of a group of rapists discharged from Swedish prisons which proved that one of the most prevalent diagnoses was personality disorder. ${ }^{121}$ Personality disorder plays a role not only in the context of sexual violence, but also in other forms of women abuse. For example, it may manifest in some men's inability "in regulating anger and other strong emotions." 122 Sometimes, hidden under such emotions may be "an undiagnosed personality disorder or psychological disorder." ${ }^{123}$ Hence,

\footnotetext{
116 Toby D. Goldsmith, "What Causes Domestic Violence?" PsychCentral https://tinyurl.com/yb4n9yc7.

117 “Personality Disorder,"Encyclopadia Britannica Student and Home Edition (Chicago: Encyclopædia Britannica, 2011).

118 "Personality Disorder,"Encyclopadia Britannica.

119 "Personality Disorder,"Encyclopadia Britannica.

120 Sandra Newman, "Why Men Rape," Aeon 30 March 2017, https://tinyurl.com/y8zl2wlt.

121 Jaydip Sarkar, "Mental Health Assessment of Rape Offenders," IJPsych 55/3 (2013): 235-243, DOI: https://doi.org/10.4103/0019-5545.117137, 237.

122 Goldsmith, "What Causes?" https://tinyurl.com/yb4n9yc7.

123 Goldsmith, "What Causes?" https://tinyurl.com/yb4n9yc7; cf. Gluck, "Causes," https://tinyurl.com/yagkd4fl.
} 
"men who justify wife beating to control and discipline their wife"124 exhibit a character disorder which is not necessarily influenced by patriarchy.

Closely linked to the factor of personality disorder is the use of alcohol and/or drugs, as it has been indicated that drug addiction and alcoholism may be traits of an antisocial disorder. The National Institute of Justice (USA) maintains that alcohol does not in itself cause violence against women, but there exists a significant relationship "between male perpetrator problem drinking [sic] and violence against intimate female partners." ${ }^{125}$ According to Living without Abuse (LWA), "domestic abuse is far more prevalent ... in households where alcohol or drugs are being misused." 126 This is because "alcohol and drugs may contribute to violent behavior [in that] a drunk or high person will be less likely to control his or her violent impulses toward their partner." ${ }^{127}$ The National Institute of Justice (NIJ) emphasises that alcoholism increases "the risk for lethal and violent victimization of women in intimate partner relationships." 128

Irrespective of the societal organisation, persistence of women abuse by men is one of the possible causes of violence against women. People who witness domestic violence in their families or community when growing up are likely to believe "that violence is a reasonable way to resolve conflict between people." 129 For example, boys who are accustomed to seeing women as undeserving of respect will likely abuse women later in life. ${ }^{130}$ In the words of Gluck:

Many experts believe psychopathology, developed by growing up in a violent and abusive household, causes domestic violence to continue as a generational legacy. Witnessing abuse as the norm, or being abused, destroys the child's ability to trust others and undermines his or her ability to control emotions. This produces hostile, dependant, and emotionally insecure people with a deeply impaired ability to develop and maintain healthy relationships. ${ }^{131}$

Low socio-economic status of a family may also be a cause of domestic violence. Gluck opines that protracted periods of unemployment and other financial issues may cause domestic violence against women. ${ }^{132}$ Similarly, the National Institute of Justice affirms that:

124 Antai, "Controlling Behavior," 3.

125 "Causes and Consequences of Intimate Partner Violence," National Institute of Justice, https://tinyurl.com/ybngjblu.

126 "Causes," https://tinyurl.com/y9r8all3.

127 Goldsmith, "What Causes?" https://tinyurl.com/yb4n9yc7.

128 "Causes and Consequences," https://tinyurl.com/ybngiblu.

129 Goldsmith, "What Causes?" https://tinyurl.com/yb4n9yc7.

130 Goldsmith, "What Causes?" https://tinyurl.com/yb4n9yc7.

131 Gluck, "Causes," https://tinyurl.com/yagkd4fl.

132 Gluck, "Causes," https://tinyurl.com/yagkd4fl. 
358 Ademiluka, "Patriarchy and Women Abuse," OTE 31/2 (2018): 339-362

severe poverty and its associated stressors increase the risk for intimate partner violence-the lower the household income, the higher the reported intimate partner violence rates. ${ }^{133}$

Merten buttresses this fact from a study in South Africa which showed that "women in the poorest households $(24.4 \%)$ were more likely to experience physical violence compared to the top earning homes (13\%)."134

In the study on rapists discharged from Swedish prisons earlier mentioned, "the most prevalent diagnoses" that were found responsible for rape among perpetrators were alcohol abuse, drug abuse, personality disorder, and psychosis. ${ }^{135}$ Also as seen above, drug addiction and alcoholism are among the traits of antisocial disorders; and thus it appears that the major causes of women abuse are personality disorders. This implies that, irrespective of the organisational system, there will always be violence against women, like other antisocial behaviours in society, as long as there are persons with personality disorders. Therefore, although finding a solution to women abuse is not within the scope of this work, it is appropriate to mention that any programme aimed at the solution to the problem will have to focus on the issue of personality disorders more than on patriarchy.

\section{CONCLUSION}

A common trait of a patriarchal culture is that it rates women lower than men in status, and concomitantly, women are oppressed by men in patriarchal cultures. Hence, many blame violence against women on patriarchy. However, with reference to ancient Israelite and African cultures, this article demonstrated that not all men women abusers, and in both contexts there is also evidence of female perpetrators of violence against men. It was also demonstrated that in ancient and modern societies, homosexual violence also occurs. I argued that there are factors that are particular to certain men that are often responsible for violence against women, the major ones being personality disorders. Personality disorders include traits such as alcoholism and drug abuse, which in themselves weaken inhibition, thereby making women abuse more likely to occur. Some men who are accustomed to domestic violence in their homes from youth grow up to adopt violence as a way of handling family disputes. Also, women abuse tends to be more common in families with low socio-economic status. Therefore, although patriarchy may induce women abuse, it is not the actual cause, and it is possible that violence against women would even occur in a matriarchal culture as long as factors such as personality disorders persist.

133 "Causes and Consequences," https://tinyurl.com/ybngiblu.

134 Marianne Merten, "Statistics SA: One in Five SA Women Experience Physical Violence, Young Women Hard-Hit by HIV/Aids," Daily Maverick 15 May 2017,https://tinyurl.com/yavuwbju.

135 Sarkar, "Mental Health," 237. 


\section{BIBLIOGRAPHY}

Ackerman, Susan. "Women in Ancient Israel and the Hebrew Bible." In Biblical Studies, Christianity, Judaism and Jewish Studies. Oxford Research Encyclopedia of Religion. Online publication April 2016. 32 pages. https://doi.org/10.1093/acrefore/9780199340378.013.45.

Ademiluka, S. Olusola. "1 Corinthians 14:33b-36 in Light of Women and Church Leadership in Nigeria." Verbum et ecclesia 38/1 (2017). Article \#1672. https://doi.org/10.4102/ve.v38i1.1672.

Adeyemi, Lere. "The Yoruba Cultural Values and the Ideology of Feminism." Pages 49-58 in Multi-disciplinary Perspectives in Nigerian Studies. Edited by Rotimi Ajayi, Olu Alana, and Yemi Akinwumi. Ilorin: Nathdex, 1998.

Agbonkhese, Josephine and Chris Onuoha. "Does Nigerian Culture Permit Domestic Violence?" Vanguard 24 August 2017, https://tinyurl.com/ybyukpcw.

Agene, Monica. "The Reality of Domestic Violence in Nigeria." Women for Women International, https://tinyurl.com/yc4g5gfv.

Goldsmith, Toby D. "Causes and Consequences of Intimate Partner Violence." National Institute of Justice. Online: https://tinyurl.com/ybngjblu.

Anon. "Rape."Encyclopadia Britannica Student and Home Edition. Chicago: Encyclopædia Britannica, 2011.

Anon. "Personality Disorder."Encyclopadia Britannica Student and Home Edition. Chicago: Encyclopædia Britannica, 2011.

Anon. "Causes and Consequences of Intimate Partner Violence." National Institute of Justice (2007). Online: https://tinyurl.com/ybngjblu.

Anon. "Intimate Partner Violence Prevention: Definitions." Centers for Disease Control and Prevention. Online: https://www.cdc.gov/violenceprevention lintimatepartnerviolence/definitions.html.

Anon. "Patriarchy," Merriam Webster Dictionary, https://tinyurl.com/y6wpaenl.

Anon. "Patriarchy." Wikipedia, https://tinyurl.com/y7yzrgzc.

Anon. "What is Patriarchy?" London Feminist Network, https://tinyurl.com/y7yzrgzc.

Antai, Diddy. "Controlling Behavior, Power Relations within Intimate Relationships and Intimate Partner Physical and Sexual Violence against Women in Nigeria." BioMed Central Public Health 11 (2011), 11 pages, https://doi.org/10.1186 /1471-2458-11-511.

Babajide-Alabi, Morak. "Let's Talk about Rape." Vanguard 17 September 2017. https://tinyurl.com/ybdrwopv.

Baffour, Katherine. "Rape in Nigeria: Sexual Predators on the Prowl." NAIJ.com, https://tinyurl.com/y74ae27n.

Baumert, Norbert, S. J. Woman and Man in Paul: Overcoming a Misunderstanding. Translated by Patrick Madigan, S. J., and Linda M. Maloney. Collegeville, Minnesota: Michael Glazier, 1996.

Becker, Mary. "Patriarchy and Inequality: Towards a Substantive Feminism." University of Chicago Legal Forum 1/3 (1999): 21-88. Article \#3. Online: https://chicagounbound.uchicago.edu /uclf/vol1999/iss1/3/.

Brockington, Leonard H. "I and II Samuel." Pages 318-337 in Peake's Commentary on the Bible. Edited by Matthew M. Black and Harold H. Rowley. Wokingham: Van Nostrand Reinhold, 1982. 
Bvukutwa, Godess. "Gender Equality is not a Western Notion.” Imagining Equality, https://tinyurl.com/y8vy6frb.

Claassens, Juliana L. "Female Resistance in Spite of Injustice: Human Dignity and the Daughter of Jephthah." Old Testament Essays 26/3 (2013): 607-22.

Coffman, James B. "Commentary on Judges 19:4." In Coffman Commentaries on the Old and New Testament. Abilene: Abilene Christian University Press, 1983-1999. Online: https://www.studylight.org/commentaries/bcc/judges-19.html.

Collins, Shiella. "Towards a Feminist Theology." Christian Century 89 (1972): $792-$ 804.

Delano, Lola. "Sexual Abuse and Violence in Sub-Saharan Africa." Advocates for Youth, https://tinyurl.com/q5her32.

Folayan, Morenike O., MorolakeOdetoyinbo, Abigail Harrison, and Brandon Brown. "Rape in Nigeria: A Silent Epidemic among Adolescents with Implications for HIV Infection.” Global Health Action 7 (2014), https://doi.org/10.3402/gha .v7.25583.

Fox, Vivian C. "Historical Perspectives on Violence against Women." JIWS 4/1 (2002):15-34. Online: http://vc.bridgew.edu/jiws/vol4/iss 1/2/.

Gelles, Richard J. "Domestic Violence." Microsoft Encarta 2009 [DVD]. Redmond, WA: Microsoft Corporation, 2008.

Gluck, Samantha. "Causes of Domestic Violence, Domestic Abuse." Healthy Place, https://tinyurl.com/yagkd4fl.

Goldsmith, Toby D. "Causes of Domestic Abuse." Psych Central (2016): Online: https://tinyurl.com/y9r8all3.

Graetz, Naomi. "Domestic Violence in Jewish Law." My Jewish Learning, https://tinyurl.com/ycw9bnue.

Graybill, Rhiannon. "Teaching about Sexual Violence in the Hebrew Bible." Oxford Biblical Studies Online, https://tinyurl.com/yd9s887q.

Guarneri, Christine and Dudley L. Poston Jr. "Patriarchy." IESS. https://www.encyclopedia.com/social-sciences-and-law/anthropology-andarchaeology/anthropology-terms-and-concepts/patriarchy.

Harris, R. Laird, Gleason L. Archer, Jr., and Bruce K. Waltke, eds. Theological Wordbook of the Old Testament. 2 vols. Chicago: Moody Publisher, 1980.

Hasstedt, Kinsey and Andrea Rowan. "Understanding Intimate Partner Violence as a Sexual and Reproductive Health and Rights Issue in the United States." Guttmacher Policy Review 19 (2016): 37-45. Online: https://tinyurl.com/ybup2fpn.

Igbelina-Igbokwe, Nkiru. "Contextualizing Gender Based Violence within Patriarchy in Nigeria." Pambzuka News: Voices for Freedom and Justice (2013): 12 pages. Online: https://www.pambazuka.org/gender-minorities/contextualizing-genderbased-violence-within-patriarchy-nigeria.

Jacobs, Sandra. "Terms of Endearment? The Desirable Female Captive and her Illicit Acquisition." Pages 237-57 in Exodus and Deuteronomy. Edited by Athalya Brenner and Gale A. Yee. Minneapolis: Fortress, 2012. https://doi.org/10.2307 /j.ctt22nm70p.22

Kalichman, Seth C., Leickness C. Simbayi, Michelle Kaufman, Demetria Cain, Chauncey Cherry, and Sean Jooste. "Gender Attitudes, Sexual Violence, and HIV/AIDS Risks among Men and Women in Cape Town, South Africa." Journal 
of Sex Research 42/4 (2005): 299-305. https://doi.org/10.1080/00224490509 552285.

Kealotswe, Obed N. "Biblical and African Forms of Marriage and Old Testament Prophecy: An Interpretation of Isaiah 4:1 in the Era of HIV/AIDS by an African Independent Church Leader in Botswana." Theologia Viatorum 33/3 (2009): 296321.

Kirk-Duggan, Cheryl A. "Precious Memories: Rule of Law in Deuteronomy as Catalyst for Domestic Violence." Pages 258-88 in Exodus and Deuteronomy. Edited by Athalya Brenner and Gale A. Yee. Minneapolis: Fortress, 2012. https://doi.org/ 10.2307/j.ctt22nm70p.23

Klopper, Frances. "Rape and the Case of Dinah: Ethical Responsibilities for Reading Genesis 34." Old Testament Essays 23/3 (2010): 652-65.

Masenya, Madipoane J. "Drippling Nails, Desire and Polygynous Partnerships: Navigating Women's Stories in Gen 29-30 through African Love Song(s)." Theologia Viatorum 36/1 (2012): 125-40.

Merten, Marianne. "Statistics SA: One in Five SA Women Experience Physical Violence, Young Women Hard-Hit by HIV/Aids.” Daily Maverick 15 May 2017, https://tinyurl.com/yavuwbju.

Mkhize, Zweli. "Patriarchy: A Catalyst for Gender Violence and Discrimination." Daily Maverick 18 September 2017, https://tinyurl.com/yc2srjya.

Mokgata, Kholofelo. "African Culture Should Adopt Feminism: A Look at how Patriarchy has Tarnished African Culture." Unlabelled, https://tinyurl.com/ya5o5fog.

Newman, Sandra. "Why Men Rape." Aeon 30 March 2017, https://tinyurl.com/ y8zl2wlt.

Okenwa, Leah, Stephen Lawoko, and Bjarne Jansson. "Factors Associated with Disclosure of Intimate Partner Violence among Women in Lagos, Nigeria." Journal of Injury and Violence Research 1/1(2009):37-47. https://doi.org/10. 5249/jivr.v1i1.15.

Olajubu, Oyeronke. "Culture as an Empowering Tool in Africa: A Feminist Perspective." Pages 60-69 in Multi-Disciplinary Perspectives in Nigerian Studies. Edited by Rotimi Ajayi, Olu Alana, and Yemi Akinwumi. Ilorin: Nathadex, 1998.

Ose, N. Aihie. "Prevalence of Domestic Violence in Nigeria: Implications for Counseling." Edo Journal of Counselling 2/1 (2009). 8 pages. https://doi.org/ $\underline{10.4314 / \text { ejc.v2i1.52648 }}$

Robinson, B. A. "Passages in the Hebrew Scriptures (Old Testament) that Treat Women as Inferior to Men." Religious Tolerance, https://tinyurl.com/b7dv9.

Sarkar, Jaydip. "Mental Health Assessment of Rape Offenders." Indian Journal of Psychiatry 55/3 (2013): 235-243. https://doi.org/10.4103/0019-5545.117137.

Schultz, John. "Genesis 19 - Commentary." Online: https://tinyurl.com/ycopw77o.

Smith, Charles W. "Commentary on 2 Samuel 16:4." Chuck Smith Bible Commentary (2014). Online: https://tinyurl.com/y9ctcja8.

Wenham, Gordon J. "Genesis." Pages 54-91 in New Bible Commentary. Edited by Donald. A. Carson, Gordon J. Wenham, J. Alec Motyer, and Richard T. France. Nottingham: IVP, 1994. 
362 Ademiluka, "Patriarchy and Women Abuse," OTE 31/2 (2018): 339-362

Solomon Olusola Ademiluka (Unisa), Department of Biblical and Ancient Studies, University of South Africa; Department of Religious Studies, Kogi State University, Anyigba, Nigeria; solademiluka@ gmail.com; +2347036127452; All private correspondence to P. O. Box, 379, Anyigba, Kogi State, Nigeria. ORCID ID: https://orcid.org/0000-0001-9390-2510 